Cowan, S. T., Shaw, C. \& Williams, R. E. O. (1954). J. gen. Microbiol. 10, 174-176.

\title{
Type Strain for Staphylococcus aureus Rosenbach
}

\author{
By S. T. COWAN and CONSTANCE SHAW \\ National Collection of Type Cultures \\ AND R. E. O, WILLIAMS \\ Staphylococcal Reference Laboratory, Public Health Laboratory Service, \\ Colindale Avenue, London, N.W. 9
}

SUMMARY : A strain isolated from a human source is described and is proposed as the type for the species Staphylococcus aureus Rosenbach in place of the one chosen by Shaw, Stitt \& Cowan (1951) which has some characters of animal strains.

The nomenclatural type concept in bacteriology dates from the selection of the Marburg strain of Bacillus subtilis as the type strain of that species (St John-Brooks \& Breed, 1937). Rule 9 of the bacteriological code (Buchanan, St John-Brooks \& Breed, 1948) states that 'For each valid name of each taxonomic group there shall be designated a type; that is for each species or subspecies a type culture, specimen or description, for each genus a type species (genotype).' It is proposed (Editorial Board, 1953) that this rule shall be amended to indicate more precisely how the type strain shall be chosen when the original author of a name did not preserve the culture on which he based his description. A substitute type culture (neotype culture) should be one accepted by international agreement; 'It should agree with the diagnosis given by the original describer, and should be recommended by a Committee of workers familiar with the species and approved by the Judicial Commission' (Editorial Board, 1953, p. 43, draft proposal 14).

Rosenbach (1884) adopted Ogston's (1882) generic name Staphylococcus, and named two species, Staphylococcus aureus and Staphylococcus albus, both based on organisms isolated from infective processes in man. He did not choose a type culture, and we do not know of the existence of any of Rosenbach's original cultures. Consequently, when Shaw, Stitt \& Cowan (1951) reviewed the classification and nomenclature of staphylococci, they selected as type a strain, FDA 209-P, maintained in the American Type Culture Collection (ATCC 6538P) and in the National Collection of Type Cultures (NCTC 7447). Gibson (1953) has asked for an official Opinion of the Judicial Commission on the validity of the generic name Staphylococcus, and has proposed that the culture FDA 209-P should be recognized as the type culture of Staphylococcus aureus Rosenbach.

Before designating it as a type strain Shaw et al. (1951) examined the cultural characters of FDA 209-P, and chose it because: (1) it was wellpigmented and on subculture retained its ability to produce pigment; (2) its biochemical characters were fairly typical of the species; (3) the strain was in use as a reference strain for penicillin assay and was held in at least two of the major bacterial culture collections. Recently an attempt was made to 
classify the strain by bacteriophage and serological methods; it was found to be bacteriophage type $42 \mathrm{D}$, and serologically untypable. Bacteriophage type 42D is associated with infections of cattle, and it seems probable that FDA 209-P is not of human origin.

We think that the neotype culture of Staphylococcus aureus should be a strain isolated from a pathological lesion in man and that it should have characters associated with other human strains. Consequently we withdraw our earlier choice of FDA 209-P as the neotype culture of Staphylococcus aureus and propose in its place strain $\mathrm{S33R}_{4}$, a description of which follows.

\section{DESCRIPTION OF PROPOSED NEOTYPE CULTURE S $33 \mathrm{R}_{4}$}

History of the strain. Isolated on 13 November 1935, from a specimen of human pleural fluid which contained acid-fast bacilli. Maintained by subculture in nutrient agar stabs and passaged through four rabbits before preservation in the dry state in March 1939. Deposited in the National Collection of Type Cultures in May 1953 (NCTC 8532).

Metabolism. The strain is an aerobe and facultative anaerobe. It grows equally well at 30 and at $37^{\circ}$. It is not able to utilize citrate as the sole carbon source, or ammonium salts as the sole nitrogen source.

Morphology. The organisms are Gram-positive, spherical or near spherical in shape, $0 \cdot 7-1.0 \mu$ in diameter, and arranged in pairs or small grape-like clusters. They have not been found to be motile, and they do not spore.

Colony form. After 24 hr. at $37^{\circ}$ on Lemco agar colonies are 0.5-1.0 mm. in diameter. They have a low convex elevation, a smooth shining surface and an entire edge. When left at room temperature in diffused daylight colonies increase in size and become coloured with a rich cream or gold pigment. The colonies are opaque, butyrous in consistency, and the growth is easily emulsifiable. On agar containing $5 \%(\mathrm{v} / \mathrm{v})$ horse blood, colonies are surrounded by clear zones of haemolysis.

Broth culture. After $24 \mathrm{hr}$. at $37^{\circ}$ the medium shows a dense general turbidity and a powdery deposit, moderate in amount. With continued incubation the bulk of the deposit increases and a ring pellicle forms on the surface.

Gelatin stab. Growth along the needle track shows the first signs of liquefying the medium after $24 \mathrm{hr}$. at $22^{\circ}$. At $48 \mathrm{hr}$. there is saccate liquefaction extending to the limit of the inoculation.

Bromcresol purple milk. Acid after 1 day, clot after 5 days at $37^{\circ}$. Slight digestion of clot begins about the 7 th day.

Biochemical reactions. The methyl red and Voges-Proskauer tests are positive after 5 days at $30^{\circ}$. At $37^{\circ}$ ammonia is produced from peptone, but neither $\mathrm{H}_{2} \mathrm{~S}$ nor indole is produced from media containing adequate amounts of sulphydryl compounds and tryptophan; nitrates are reduced to nitrites; catalase is produced on Lemco agar; starch is not hydrolysed; urease is produced. The strain is phosphatase-positive (Barber, Brooksbank \& Kuper, 1951). On egg-yolk agar at $37^{\circ}$ (Gillespie \& Alder, 1952) a slight opacity is produced around the colonies. Inspissated serum is not digested within 7 days at $37^{\circ}$. 
Fermentation reactions. At $37^{\circ}$ acid is produced from glucose, xylose, lactose, sucrose, maltose, glycerol and mannitol, but not from dulcitol or salicin.

Special characters. The coagulase produced by this strain clots human and rabbit plasma. $\alpha$-Toxin is produced in an atmosphere of $20 \%(\mathrm{v} / \mathrm{v}) \mathrm{CO}_{2}$. The strain is sensitive to penicillin, streptomycin, aureomycin and chloramphenicol, and is resistant to sulphathiazole. Serologically it is type III (Cowan, 1939), of which it is the type strain.

The strain is lysed strongly by the following bacteriophages of the standard set used in the routine typing method described in the appendix to the report of Williams, Rippon \& Dowsett (1953): 6, 7, 47, 54, 75. It is, in addition, lysed strongly by two other phages not now ordinarily used in routine typing, namely $75 \mathrm{~A}$ and $75 \mathrm{~B}$. When tested with undiluted filtrates the strain is lysed strongly by the following phages of the standard set: $6,7,42 \mathrm{E}, 47,53,54,70$, $73,75,77$; and also by the following additional phages: $42 \mathrm{~B}, 42 \mathrm{~F}, 47 \mathrm{~B}, 47 \mathrm{C}$, $52 \mathrm{~B}, 57,58,75 \mathrm{~A}, 75 \mathrm{~B}, 76,78$.

The strain is a typical member of the group III defined by Williams et al. (1953).

\section{REFERENCES}

Barber, M., Brooksbank, B. W. L. \& Kuper, S. W. A. (1951). Staphylococcal phosphatase, glucuronidase and sulphatase. J. Path. Bact. 63, 57.

Buchanan, R. E., St John-Brooks, R. \& Breed, R. S. (1948). International bacteriological code of nomenclature. J. Bact. 55, 287. Reprinted 1949 in J. gen. Microbiol. 3, 444.

Cowan, S. T. (1939). Classification of staphylococci by slide agglutination. J. Path. Bact. 48, 169.

Edtorial Board (1953). The international bacteriological code of nomenclature: proposals relative to emendation and publication. Int. Bull. bact. Nom. Tax. 3, 31.

Gibson, T. (1953). The status of the generic names Micrococcus and Staphylococcus and of the species name Staphylococcus aureus. Int. Bull. bact. Nom. Tax. 3, 129.

Gillespie, W. A. \& Alder, V. G. (1952). Production of opacity in egg-yolk media by coagulase-positive staphylococci. J. Path. Bact. 64, 187.

Ogston, A. (1882). Micrococcus poisoning. J. Anat., Lond. 17, 24.

Rosenbach, F. J. (1884). Mikroorganismen bei den Wundinfectionskrankheiten des Menschen. Wiesbaden: J. F. Bergmann.

St John-Brooks, R. \& Breed, R. S. (1937). Actions taken by the second international microbiological congress in London, 1936, regarding bacteriological nomenclature. J. Bact. 33, 445.

Shaw, C., StitT, J. M. \& Cowan, S. T. (1951). Staphylococci and their classification. J. gen. Microbiol. 5, 1010.

Williams, R. E. O., Rippon, J. E. \& Dowsett, L. M. (1953). Bacteriophage typing of strains of Staphylococcus aureus from various sources. Lancet, i, 510. 